\title{
Potensi Seduhan Limbah Baglog Jamur Tiram (Pleurotus ostreatus) dalam Menekan Populasi Radopholus similis dan Meloidogyne spp. pada Tanah Asal Perakaran Tanaman Lada (Piper nigrum L)
}

\author{
Infusion of Oyster Mushroom (Pleurotus ostreatus) Baglog \\ Waste to Suppress The Population of Radopholus similis and \\ Meloidogyne spp. In The Rhizosphere of Pepper Plant (Piper \\ ningrum $\mathrm{L}$ )
}

\author{
Ankardiansyah Pandu Pradana, Diana Putri, dan Abdul Munif. \\ Departemen Proteksi Tanaman, Fakultas Pertanian, Institut Pertanian Bogor, Bogor 16680, Indonesia
}

Diterima 28 Agustus 2016/Disetujui 30 September 2016

\begin{abstract}
Indonesia is one of the largest pepper producing countries in the world. One of the pepper-producing provinces in Indonesia is the Bangka Belitung Islands (Babel). However, the infection of Radopholus similis and Meloidogyne spp. which causes yellow disease becomes one of obstacles in pepper cultivation in Babel. Thus, alternative solution to overcome this yellow disease is by reducing the amount of nematode inoculum of $R$. similis and Meloidogyne spp. in soil. This study aimed to determine the effectiveness of the infusion of oyster mushrooms baglog waste enriched with molasses to control the population of $R$. similis and Meloidogyne spp. and to increase the population of rhizobacteria. Infusion of oyster mushrooms baglog waste was mixed with $1 \%$ of molasses and was poured into soil obtained from the pepper plant roots. The concentrations used were $10 \%, 20 \%, 30 \%$ and $50 \%$. Population of phytonematode, rhizobacteria, proteolytic bacteria, and group of fluorescence bacteria were calculated before and 7 days after treatment. Results showed that the populations of $R$. similis and Meloidogyne spp. in the soil poured with the influsion of oyster mushroom baglog waste decreased by $29.11 \%$ ( $R$. similis) and $24.61 \%$ (Meloidogyne spp.), compared to the before and control treatments. The suppression of nematode population was found to be the highest in the influsion treatment at concentration of $50 \%$. Overall, treatment of all concentrations succeeded to increase the population of rhizobacteria, proteolytic bacteria, and group of fluorescence bacteria in soil. Moreover, the highest increase was found in soil treated with concentration of $50 \%$. This study provided new information that the infusion application of oyster mushrooms baglog waste enriched with molasses had the potential to increase the population of rhizobacteria and suppress the amount of pathogens $R$. similis and Meloidogyne spp.
\end{abstract}

Key words: phytonematode, fluorescence, molasses, proteolytic, rhizobacteria

\section{PENDAHULUAN}

Lada merupakan salah satu komoditas perkebunan andalan Indonesia. Pada bulan Januari sampai dengan Juni 2016 Indonesia mengekspor lada sebanyak 15.644.053 kg dengan nilai ekspor mencapai USD 143.586.267 (Kementan 2016a). Sebagai negara pengekspor lada terbesar di dunia, Indonesia perlu memperhatikan keberlanjutan produksi lada. Pusat produksi lada di Indonesia tersebar di berbagai daerah seperti Kalimantan Barat, Kalimantan Timur, dan Kepulauan Bangka Belitung (Babel). Saat ini Babel

*Penulis korespondensi. Phone: +628121107021 E-mail: abdulmunif@ipb.ac.id merupakan daerah penghasil lada terbesar di Indonesia (Kementan 2016b).

Beberapa masalah yang dialami petani lada di Babel antara lain; (1) fluktuasi harga lada, (2) gangguan organisme penganggu tanaman (OPT), dan (3) pengembangan komoditas perkebunan lain (Mustika 2005). Salah satu akibat dari gangguan OPT pada tanaman lada adalah munculnya penyakit kuning. Penyakit kuning dapat menyebabkan kehilangan hasil panen lada. Beberapa peneliti melaporkan penyebab penyakit kuning adalah infeksi fitonematoda Meloidogyne spp., Radopholus similis (Daras \& Pranowo 2009; Thuy et al. 2012), dan fungi Fusarium oxysporum (Shahnazi et al. 2012).

Infeksi fitonematoda menyebabkan akar tanaman 
lada menjadi rusak, terdapat luka nekrosis dan puru (bintil). Kerusakan akar berpengaruh terhadap penyerapan air dan nutrisi dari tanah (Dropkin 1969). Terhambatnya penyerapan nutrisi menyebabkan pertumbuhan tanaman terhambat, daun menguning, selanjutnya daun dan buah menjadi gugur (Harni \& Munif 2012).

Salah satu solusi untuk mengatasi penyakit kuning adalah mengurangi jumlah inokulum nematoda di tanah (Mustika 2005). Produksi siderofor dan enzim lisis (protease dan kitinase) dari rizobakteri berpotensi dimanfaatkan untuk menekan jumlah inokulum nematoda di tanah. Siddiqui et al. (2005) melaporkan enzim protease ektraseluler yang diproduksi oleh Pseudomonas fluorescens galur CHA0 mampu menyebabkan kematian pada juvenil 2 (J2) M. incognita.

Limbah baglog jamur tiram (Pleurotus ostreatus) merupakan salah satu bahan yang mengandung protein. Aminudi (2013) melaporkan seduhan limbah baglog jamur tiram basah ditambah molase tanpa aerasi berpotensi menekan populasi J2 Meloidogyne spp. Selain berpotensi menekan populasi J2 $M$. incognita, protein yang terkandung di dalam limbah baglog jamur juga berpotensi sebagai substrat bagi bakteri proteolitik (Johan 2014). Sampai saat ini belum terdapat laporan pengaruh seduhan limbah baglog jamur tiram terhadap populasi rizobakteri, dan pengaruhnya terhadap nematoda $R$. similis.

Penelitian ini bertujuan memperoleh informasi pengaruh aplikasi seduhan limbah baglog jamur tiram terhadap populasi $R$. similis dan Meloidogyne spp. serta populasi rizobakteri pada tanah asal tanaman lada.

\section{BAHAN DAN METODE}

Penyediaan Seduhan Limbah Baglog Jamur Tiram. Baglog jamur yang digunakan berasal dari pembudidayaan jamur tiram di daerah Ciomas, Bogor. Baglog jamur dicacah sampai halus, kemudian ditambah akuades dengan perbandingan 4:1, lalu direbus. Setelah direbus seduhan tersebut disaring menggunakan saringan 50 mesh untuk mendapatkan hasil seduhan yang bersih. Molase ditambahkan kedalam seduhan sebanyak $1 \%$ dari volume total. Selanjutnya seduhan limbah baglog jamur tiram siap digunakan untuk uji lanjut (Aminudi 2013).

Penyediaan Tanah Terinfestasi $R$. similis dan Meloidogyne spp. Tanah diambil dari daerah perakaran tanaman lada yang menunjukkan gejala penyakit kuning. Lokasi pengambilan tanah berada di Desa Petaling, Kecamatan Mendo Barat, Kabupaten Bangka, Provinsi Kepulauan Bangka Belitung. Tanah diambil atas izin pemilik lahan.
Aplikasi Seduhan Limbah Baglog Jamur Tiram Pada Sampel Tanah. Sebanyak $200 \mathrm{~mL}$ sampel tanah dimasukkan ke dalam gelas plastik dengan diameter $9 \mathrm{~cm}$. Selanjutnya, $50 \mathrm{~mL}$ seduhan limbah baglog jamur tiram disiram ke sampel tanah, lalu diaduk sampai seduhan merata ke seluruh bagian tanah. Konsentrasi seduhan yang diuji adalah $10 \%, 20 \%, 30 \%$, dan $50 \%$. Setelah disiram dengan seduhan limbah baglog jamur tiram, sampel tanah diinkubasi selama 1 minggu. Sebagai kontrol sampel tanah disiram menggunakan $50 \mathrm{~mL}$ akuades. Setiap perlakuan diulang 2 kali. Analisis populasi nematoda $R$. similis, dan Meloidogyne spp. serta rizobakteri dilakukan setelah masa inkubasi (Aminudi 2013).

Analisis Populasi $R$. similis dan Meloidogyne spp. Analisis populasi $R$. similis dan Meloidogyne spp. dilakukan sebelum dan sesudah aplikasi seduhan limbah baglog jamur tiram. Ekstraksi nematoda dari tanah dilakukan menggunakan metode flotasisentrifugasi. Sebanyak $200 \mathrm{~mL}$ tanah dicampur dengan $1500 \mathrm{~mL}$ air, kemudian diaduk dan dibiarkan 30 detik. Suspensi disaring menggunakan saringan bertingkat 20 mesh, 50 mesh, dan 500 mesh. Nematoda yang terdapat pada saringan 500 mesh dimasukkan ke dalam tabung sentrifugasi dengan volume $15 \mathrm{~mL}$. Suspensi kemudian disentrifugasi dengan kecepatan $3000 \mathrm{rpm}$ selama 5 menit. Supernatan hasil sentrifugasi dibuang, kemudian pelet yang terbentuk dicampur dengan larutan gula $40 \%$, lalu dikocok sampai homogen. Campuran pelet dan larutan gula tersebut kemudian disentifugasi lagi dengan kecepatan $3000 \mathrm{rpm}$ selama 1 menit. Supernatan yang terbentuk disaring menggunakan saringan 500 mesh. Nematoda yang terdapat pada saringan 500 mesh dibilas menggunakan air mengalir sampai larutan gula hilang. Selanjutnya nematoda dapat diamati (Whitehead \& Hemming 1965).

Analisis Populasi Bakteri. Populasi bakteri dianalisis sebelum dan sesudah aplikasi seduhan limbah baglog jamur tiram. Pengamatan dilakukan pada populasi rizobakteri, bakteri proteolitik, dan bakteri kelompok fluorescens.

Populasi Rizobakteri. Sebanyak $1 \mathrm{~g}$ tanah diambil dan dilarutkan dalam $9 \mathrm{~mL}$ akuades steril. Suspensi kemudian diencerkan secara bertingkat. Hasil pengenceran diambil $0.1 \mathrm{~mL}$ lalu ditumbuhkan pada media nutrient agar (NA). Pengamatan dilakukan dengan menghitung koloni bakteri yang tumbuh setelah 48 jam. Pengujian ini diulang sebanyak 2 kali (Germida \& De Freitas 2007).

Populasi Bakteri Proteolitik. Medium uji yang digunakan adalah skim milk agar (SMA). Sebanyak $30 \mathrm{~g}$ TSB $+15 \mathrm{~g}$ agar-agar bakto $+900 \mathrm{~mL}$ akuades disterilasi menggunakan autoklaf dengan suhu 121 
${ }^{\circ} \mathrm{C}$ dan tekanan 15 psi (2 atm) selama 20 menit. Media tersebut kemudian didinginkan hingga suhu $40-50{ }^{\circ} \mathrm{C}$, dan ditambahkan dengan susu skim $(10 \mathrm{~g}$ susu skim dalam $100 \mathrm{~mL}$ akuades) yang disterilisasi pada suhu $110{ }^{\circ} \mathrm{C}$ selama 10 menit. Media TSA dan susu dicampur hingga rata kemudian dituang ke dalam cawan petri. Suspensi hasil pengenceran yang digunakan pada penghitungan populasi bakteri total diambil sebanyak $0.1 \mathrm{~mL}$, kemudian ditumbuhkan pada media SMA. Setelah 48 jam diamati jumlah koloni bakteri yang tumbuh dan menyebabkan zona bening pada media. Pengujian ini diulang sebanyak 2 kali (Baehaki \& Budiman 2011).

Populasi Bakteri Kelompok Fluorescens. Pengujian dilakukan pada media King's B dengan komposisi : $20 \mathrm{~g}$ pepton, $1.5 \mathrm{~g} \mathrm{~K}_{2} \mathrm{HPO}_{4}, 1.5 \mathrm{~g}$ $\mathrm{MgSO}_{4}, 15 \mathrm{~mL}$ gliserol, $15 \mathrm{~g}$ agar-agar bakto, dan $1000 \mathrm{~mL}$ akuades. Suspensi hasil pengenceran yang digunakan pada penghitungan populasi bakteri total diambil sebanyak $0.1 \mathrm{~mL}$, kemudian ditumbuhkan pada media. Setelah 48 jam diamati jumlah koloni bakteri yang tumbuh dan berpendar dibawah cahaya ultra violet (360 nm) (King et al. 1954).

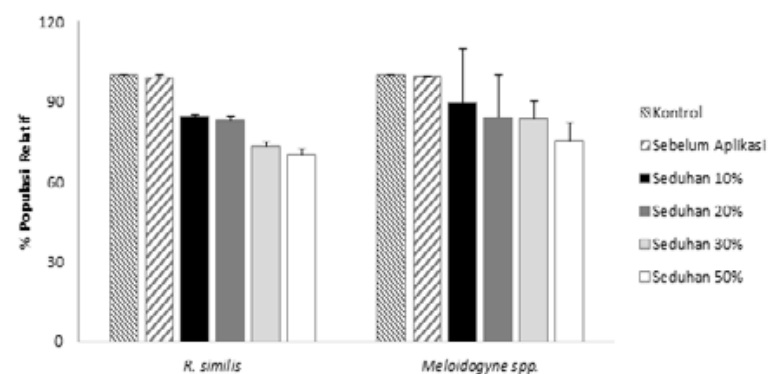

Gambar 1 Populasi R. similis dan Meloidogyne spp. pada perlakuan berbagai konsentrasi seduhan limbah baglog jamur tiram pada tanah asal perakaran tanaman lada

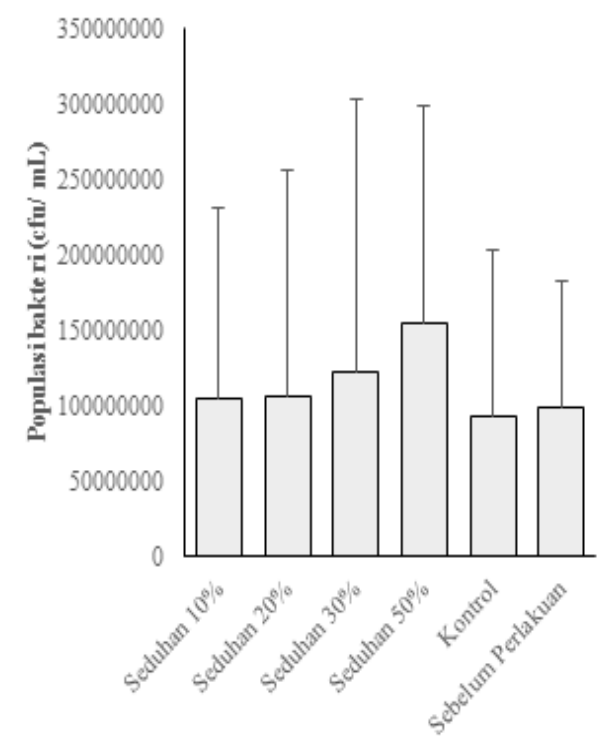

Gambar 2 Populasi rizobakteri pada perlakuan berbagai konsentrasi seduhan limbah baglog jamur tiram pada tanah asal perakaran tanaman lada
Populasi Rizobakteri. Peningkatan populasi rizobakteri semakin tinggi seiring dengan konsentrasi aplikasi seduhan limbah baglog jamur tiram. Populasi rizobakteri pada tanah kontrol dan sebelum aplikasi tidak berbeda jauh. Populasi rizobakteri pada aplikasi seduhan limbah baglog jamur tiram meningkat $11.74 \%$ (konsentrasi 10\%), 13.88\% (konsentrasi 20\%), 30.89\% (konsentrasi 30\%), dan $65.48 \%$ (konsentrasi 50\%) dibandingkan dengan kontrol (Gambar 2). Peningkatan populasi bakteri juga terjadi pada bakteri proteolitik dan bakteri dari kelompok fluorescens. Secara berurutan populasi bakteri proteolitik dan kelompok fluorescens meningkat sebesar $5.86 \%$ dan $117.5 \%$ (konsentrasi 10\%), $28.44 \%$ dan $173.19 \%$ (konsentrasi $20 \%$ ), $84.75 \%$ dan $229.37 \%$ (konsentrasi 30\%), 175.66\% dan 291.87\% (konsentrasi 50\%) (Gambar 3 dan 4).

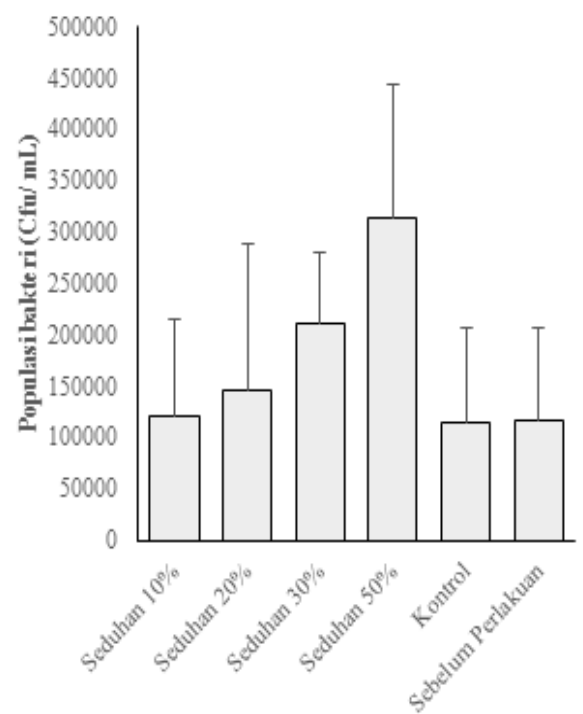

Gambar 3 Populasi bakteri proteolitik pada perlakuan berbagai konsentrasi seduhan limbah baglog jamur tiram pada tanah asal perakaran tanaman lada

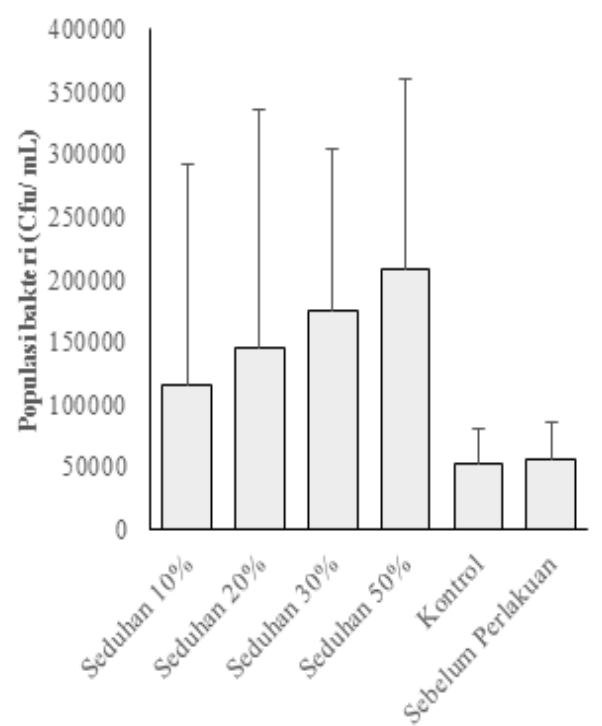

Gambar 4 Populasi bakteri kelompokftuorescens pada perlakuan berbagai konsentrasi seduhan limbah baglog jamur tiram pada tanah asal perakaran tanaman lada 


\section{HASIL}

Populasi R. similis dan Meloidogyne spp. Populasi R. similis dan Meloidogyne spp. pada tanah yang diberi aplikasi limbah baglog jamur tiram lebih rendah dibandingkan dengan kontrol dan sebelum aplikasi. Semakin tinggi konsentrasi seduhan yang diaplikasikan menyebabkan populasi $R$. similis dan Meloidogyne spp. semakin menurun (Gambar 1).

Penurunan populasi R. similis dan Meloidogyne spp. secara berurutan terjadi sebesar $14.22 \%$ dan $11.02 \%$ (konsentrasi 10\%), 15.81\% dan 16.41\% (konsentrasi 20\%), 25.69\% dan 16.41\% (konsentrasi 30\%), $29.11 \%$ dan $24.61 \%$ (konsentrasi 50\%).

\section{PEMBAHASAN}

Seduhan limbah baglog jamur tiram telah diuji sebelumnya oleh Aminudi (2013) untuk mengendalikan nematoda puru akar (NPA) Meloidogyne spp. pada tomat. Aplikasi seduhan ini efektif menekan jumlah puru pada akar tanaman tomat terinfeksi NPA, dan tidak bersifat fitotoksik pada tanaman tomat. Selain keefektifannya sebagai bahan pengendali NPA pada tomat, seduhan limbah baglog jamur sangat potensial untuk diaplikasikan karena mudah didapat, murah, dan merupakan usaha menambah nilai manfaat dari limbah ini. Baglog jamur dibuat dari bahan-bahan alami sehingga kandungan bahan kimia sintetis yang terdapat di dalamnya relatif kecil (Winarni \& Rahayu 2002).

Saat ini pengendalian OPT secara terpadu sangat direkomendasikan pada petani. Salah satu bentuk pengendalian yang disarankan adalah aplikasi bahanbahan alami untuk mengurangi tingkat infeksi atau serangan OPT. Bahan alami direkomendasikan karena aman bagi lingkungan, petani, dan konsumen (Bailey \& Lazarovits 2003; Ghorbani et al. 2008). Pada lain sisi timbulnya resistensi patogen pada aplikasi bahan alami juga relatif kecil (Tilman et al. 2002).

Populasi mikroba tanah baik yang bermanfaat maupun patogen akan berubah sesuai kondisi lingkungan tanah. Perubahan $\mathrm{pH}$, komposisi tanah, kandungan bahan organik dan anorganik akan berpengaruh terhadap komunitas mikroba yang hidup pada suatu tanah. Hal tersebut terjadi karena mikroba memiliki bioekologi yang spesifik di suatu lingkungan (Johri et al. 2003; He \& Yang 2007). Pernyataan di atas menujukkan bahwa aplikasi suatu bahan yang berasal dari luar ekosistem akan berdampak pada perubahan komunitas mikroba pada ekosistem tersebut.

Rizobakteri telah dilaporkan efektif menekan inokulum Meloidogyne spp. Selain menekan jumlah inokulum, rizobakteri juga menghambat penetasan telur Meloidogyne spp (Khan \& Akram 2000; Siddiqui \& Akhtar 2009). Beberapa spesies rizobakteri yang dilaporkan efektif sebagai agens biokontrol terhadap Meloidogyne spp. adalah Pseudomonas putida, P. alcaligenes, Paenibacillus polymyxa, dan Bacillus pumilus. Mekanisme rizobakteri dalam mengendalikan nematoda patogen adalah dengan produksi senyawa sianida dan enzim lisis (Siddiqui et al. 2007).

Seduhan limbah baglog jamur tiram memiliki nutrisi yang dibutuhkan oleh mikroba seperti fungi dan bakteri untuk bertahan hidup. Nutrisi tersebut berasal dari baglog jamur tiram yang tersusun atas beberapa bahan organik, dan molase yang ditambahkan pada seduhan (Johan 2014). Molase merupakan produk sampingan dari pengolahan tebu menjadi gula. Meskipun molase sebagai produk samping dari pembuatan gula, namun molase masih memiliki $55.37 \%$ total gula, $30.62 \%$ sukrosa, $3.89 \%$ protein, $20.33 \%$ air, dan $13.09 \%$ abu (Rahmasari 2001). Populasi mikroba di rizosfer tanaman lada semakin meningkat seiring dengan meningkatnya konsentrasi seduhan limbah baglog jamur tiram yang diaplikasikan. Semakin tinggi konsentrasi seduhan yang diaplikasikan pada rizosfer tanaman lada, maka nutrisi yang terkandung juga semakin tinggi, sehingga mendukung bagi perkembangan mikroba. Populasi mikroba tanah yang semakin meningkat diduga menjadi penyebab menurunnya populasi fitonematoda pada tanah yang sama.

Enzim protease yang dihasilkan oleh bakteri proteolitik mampu menyebabkan kematian juvenil 2 nematoda puru akar. Selain menyebabkan kematian enzim protease juga menyebabkan telur Meloidogyne tidak dapat menetas. Salah satu penyusun dinding sel nematoda adalah protein. Keberadaan enzim protease dapat menyebabkan degradasi dinding sel nematoda (Bonants et al. 1995; Sela et al. 1998; Siddiqui et al. 2005). Protease adalah enzim yang mampu memutus ikatan peptida protein. Terdapat dua jenis protease, yaitu endopeptidase dan eksopeptidase (Nishimura et al. 1983).

Tanah yang diberi perlakuan dengan seduhan limbah baglog jamur tiram mengandung bakteri lebih banyak dibandingkan dengan kontrol dan sebelum perlakuan. Seduhan limbah baglog jamur tiram dicampur menggunakan molase. Molase memiliki struktur kimia yang lebih sederhana bila dibandingkan dengan selulosa dan lignin. Meskipun molase memiliki nisbah $\mathrm{C} / \mathrm{N}$ yang tinggi, molase tergolong bahan yang mudah untuk didekomposisi oleh mikroba (Rahmasari 2001).

Bakteri proteolitik adalah bakteri yang 
memproduksi enzim protease ekstraseluler. Setiap bakteri di alam sebenarnya mampu memproduksi enzim protease, namun tidak semua bakteri mengeluarkan enzim tersebut ke luar sel (Olajuyigbe \& Ajele 2005). Enzim protease dapat memecah protein menjadi senyawa yang lebih sederhana. Protein memiliki struktur yang lebih kompleks dibandingkan dengan beberapa senyawa lain. Hal ini menyebabkan protein lebih sulit terpecah menjadi senyawa yang lebih sederhana di alam. Meskipun demikian, kehadiran bakteri proteolitik mampu mempercepat proses pemecehan protein menjadi senyawa yang lebih sederhana (Bloemberg \& Lugtenberg 2001; Lugtenberg \& Kamilova 2009).

Selain populasi rizobakteri dan bakteri proteolitik, bakteri dari golongan fuorescens juga diketahui meningkat populasinya seiring peningkatan perlakuan kosentrasi seduhan baglog. Beberapa spesies bakteri dari golongan fluorescens dilaporkan memiliki kemampuan sebagai agens biokontrol. Meningkatnya kelompok bakteri fluorescens juga dipengaruhi oleh meningkatnya populasi rizobakteri secara keseluruhan (Turnbull et al. 2001).

Penelitian ini memberikan informasi baru bahwa seduhan limbah baglog jamur tiram yang diperkaya dengan molase berpotensi mengendalikan nematoda R. similis dan Meloidogyne spp., juga meningkatkan populasi rizobakteri, bakteri proteolitik, dan bakteri kelompok fluorescens. Aplikasi pada konsentrasi $50 \%$ menunjukkan performa terbaik dibandingkan dengan konsentrasi lainnya.

\section{DAFTAR PUSTAKA}

[Kementan] Kementerian Pertanian Republik Indonesia. 2016a. Basis data ekspor-impor komoditi pertanian [internet]. [diunduh 25 Agustus 2016]. Tersedia pada: http://database. pertanian.go.id/eksim/indexl.asp.

[Kementan] Kementerian Pertanian Republik Indonesia. $2016 \mathrm{~b}$. Basis data statistik pertanian [internet]. [diunduh 25 Agustus 2016]. Tersedia pada: https://aplikasi.pertanian.go.id/bdsp/ index.asp.

Aminudi. 2013. Potensi seduhan limbah baglog jamur tiram (Pleurotus ostreatus) untuk pengendalian Meloidogyne spp. pada tanaman tomat [skripsi]. Bogor (ID): Institut Pertanian Bogor.

Baehaki A, Budiman A. 2011. Isolasi dan karakterisasi protease dari bakteri tanah rawa Indralaya, Sumatera Selatan. Jurnal Teknologi dan Industri Pangan. 22(1):37-42.

Bailey K, Lazarovits G. 2003. Suppressing soil-borne diseases with residue management and organic amendments. Soil and Tillage Research. 72(2):169-180. Doi: http://dx.doi. org/10.1016/S0167-1987(03)00086-2.

Bloemberg GV, Lugtenberg BJ. 2001. Molecular basis of plant growth promotion and biocontrol by rhizobacteria. Current Opinion in Plant Biology. 4(4):343-350. Doi: http://dx.doi. org/10.1016/S1369-5266(00)00183-7.

Bonants PJ, Fitters PF, Thijs H, den Belder E, Waalwijk C, Henfling JWD. 1995. A basic serine protease from
Paecilomyces lilacinus with biological activity against Meloidogyne hapla eggs. Microbiology. 141(4):775-784. Doi: http://dx.doi.org/10.1099/13500872-141-4-775.

Daras U, Pranowo D. 2009. Kondisi kritis lada putih Bangka Belitung dan alternatif pemulihannya. Jurnal Litbang Pertanian 28(1):1-6.

Dropkin VH. 1969. Cellular responses of plants to nematode infections. Annual Review of Phytopathology 7(1):101-122. Doi: http://dx.doi.org/ 10.1146/ annurev. py.07.090169.000533.

Germida J, De Freitas J. 2007. Cultural methods for soil and rootassociated microorganisms. Soil Sampling and Methods of Analysis. Di dalam: Carter MR, Gregorich EG, editor. Soil Sampling and Methods of Analysis Second Edition. Boca Raton (USA): Taylor and Francis Group. hlm 341-353.

Ghorbani R, Wilcockson S, Koocheki A, Leifert C. 2008. Soil management for sustainable crop disease control: a review. Environmental Chemistry Letters. 6(3):149-162. Doi: http:// dx.doi.org/10.1007/s10311-008-0147-0.

Harni R, Munif A. 2012. Pemanfaatan agens hayati endofit untuk mengendalikan penyakit kuning pada tanaman lada. Jurnal Tanaman Industri dan Penyegar. 3(3):201-206.

He Z-1, Yang X-e. 2007. Role of soil rhizobacteria in phytoremediation of heavy metal contaminated soils. Journal of Zhejiang University Science B. 8(3):192-207. Doi: http:// dx.doi.org/10.1631/jzus.2007.B0192.

Johan M. 2014. Kandungan nutrisi baglog jamur tiram putih (Pleurotus ostreatus) sebagai bahan pakan ternak pada masa inkubasi yang berbeda [Skripsi]. Makasar (ID): Universitas Hasanuddin.

Johri BN, Sharma A, Virdi J. 2003. Rhizobacterial diversity in India and its influence on soil and plant health. Di dalam: Ghose TK, Ghosh P, editor. Biotechnology in India I. Berlin (DE):Springer. hlm 49-89.

Khan M, Akram M. 2000. Effects of certain antagonistic fungi and rhizobacteria on wilt disease complex of tomato caused by Meloidogyne incognita and Fusarium oxysporum f. sp. lycopersici. Nematologia Mediterranea. 28(2):139-144.

King EO, Ward MK, Raney DE. 1954. Two simple media for the demonstration of pyocyanin and fluorescin. The Journal of Laboratory and Clinical Medicine. 44(2):301-307.

Kusuma W. 2014. Kandungan nitrogen (N), fosfor (P) dan kalium (K) limbah baglog jamur tiram (Pleurotus ostreatus) dan jamur kuping (Auricularia auricula) guna pemanfaatannya sebagai pupuk [skripsi]. Makassar (ID): Universitas Hasanuddin.

Lugtenberg B, Kamilova F. 2009. Plant-growth-promoting rhizobacteria. Annual Review of Microbiology. 63:541-556. Doi: http://dx.doi.org/10.1146 /annurev. micro.62.081307.162918.

Mustika I. 2005. Penyakit Kuning Pada Tanaman Lada Dan Cara Pengendaliannya. Bogor (ID): Balai Penelitian Tanaman Rempah dan Obat. hlm 77-98.

Nishimura K, Kawamura Y, Matoba T, Yonezawa D. 1983. Classification of proteases in Antarctic krill. Agricultural and Biological Chemistry. 47(11):2577-2583. Doi: http:// dx.doi.org/10.1271/bbb1961.47.2577.

Olajuyigbe FM, Ajele JO. 2005. Production dynamics of extracellular protease from Bacillus species. African Journal of Biotechnology. 4(8):776-779.

Rahmasari D. 2001. Mempelajari proses pemurnian molases dengan metoda koagulasi [skripsi]. Bogor (ID): Institut Pertanian Bogor.

Sela S, Schickler H, Chet I, Spiegel Y. 1998. Purification and characterization of a Bacillus cereus collagenolytic/proteolytic enzyme and its effect on Meloidogyne javanica cuticular 
proteins. European Journal of Plant Pathology. 104(1):5967. Doi: http://dx.doi.org/10.1023/A:1008643414691.

Shahnazi S, Meon S, Vadamalai G, Ahmad K, Nejat N. 2012. Morphological and molecular characterization of Fusarium spp. associated with yellowing disease of black pepper (Piper nigrum L.) in Malaysia. Journal of General Plant Pathology. 78(3):160-169. Doi: http://dx.doi.org/10.1007/ s10327-012-0379-5.

Siddiqui IA, Haas D, Heeb S. 2005. Extracellular protease of Pseudomonas fluorescens CHA0, a biocontrol factor with activity against the root-knot nematode Meloidogyne incognita. Applied and Environmental Microbiology. 71(9):5646-5649. Doi: http://dx.doi.org/10.1128/ AEM.71.9.5646- 5649.2005.

Siddiqui ZA, Akhtar MS. 2009. Effect of plant growth promoting rhizobacteria, nematode parasitic fungi and root-nodule bacterium on root-knot nematodes Meloidogyne javanica and growth of chickpea. Biocontrol Science and Technology. 19(5):511-521. Doi: http://dx.doi.org/10.1080/09583150902 887792.

Siddiqui ZA, Baghel G, Akhtar M. 2007. Biocontrol of Meloidogyne javanica by Rhizobium and plant growthpromoting rhizobacteria on lentil. World Journal of Microbiology and Biotechnology. 23(3):435-441. Doi: http:// dx.doi.org/10.1007/s11274-006-9244-z.
Thuy T, Yen N, Tuyet N, Te L, De Waele D. 2012. Plant-parasitic nematodes and yellowing of leaves associated with black pepper plants in Vietnam. Archives of Phytopathology and Plant Protection. 45(10):1183-1200.

Tilman D, Cassman KG, Matson PA, Naylor R, Polasky S. 2002. Agricultural sustainability and intensive production practices. Nature. 418(6898):671-677. Doi: http://dx.doi.org/10.1038/ nature 01014.

Turnbull GA, Morgan JAW, Whipps JM, Saunders JR. 2001. The role of bacterial motility in the survival and spread of Pseudomonas fluorescens in soil and in the attachment and colonisation of wheat roots. FEMS Microbiology Ecology. 36(1):21-31. Doi: http://dx.doi. org/10.1111/j.1574-6941.2001.tb00822.x.

Whitehead A, Hemming J. 1965. A comparison of some quantitative methods of extracting small vermiform nematodes from soil. Annals of Applied Biology. 55(1):25-38. Doi: http://dx.doi.org/10.1111/j.1744-7348.1965.tb07864.x.

Winarni I, Rahayu U. 2002. Pengaruh formulasi media tanam dengan bahan dasar sberbuk gergaji terhadap produksi jamur tiram putih (Pleurotus ostreatus). Jurnal Matematika, Sains, dan Teknologi. 3(2):20-27. 